\title{
Herpes-associated erythema multiforme worsened by a Siddha drug, Alpinia galanga, in an 18-year-old man
}

\author{
Siva Kumar $\mathrm{M}_{1}{ }^{1}$ Hari Kumar $\mathrm{M}_{1}{ }^{2}$ Vishalakshi Siva Kumar, ${ }^{1}$ Sabitha Hari Kumar ${ }^{2}$
}

${ }^{1}$ Maxillo Facial Department, Doctor Kamalkanadasan Dental Clinic, Chennai, Tamil Nadu, India

${ }^{2}$ Dental Department, JEBA Dental Clinic, Nagercoil, Tamil Nadu, India

Correspondence to Dr Hari Kumar M, drhari.omrd@gmail.com

Accepted 7 September 2015

\section{DESCRIPTION}

An 18-year-old man with fever and headache for 1 week was prescribed with capsules containing Alpinia galanga by a Siddha physician.Three days later, the patient developed extensive crustations on the lower lip. A provisional diagnosis of erythema multiforme was made with this drug history and, after further investigation, herpes-associated erythema multiforme (HAEM) was made. The patient was managed with a 1 -week course of tablet acyclovir and prednisolone. This case details the role of A. galanga in exasperating HAEM and also describes its management approach.

A. galanga belongs to Zingiberaceae (the ginger family). Its rhizome (rootstock) is commonly used in herbal medicine and as a spice in food. Its pharmacological actions are anti-inflammation, antioxidation, antiallergy, gastroprotection, hypoglycaemic effect and marked immunostimulation. An erythema multiforme-like reaction caused by A. galanga is due to the haptens present in it. The haptens in A. galanga are also strong allergens to $\mathrm{T}$ cells and provoke a T-cell-mediated immune response. Mechanisms of tissue damage include direct cytotoxicity against keratinocytes, mostly mediated by CD8 $+\mathrm{T}$ cells, and the $\mathrm{T}$-cell release of cytokines that amplify the inflammatory response by targeting resident skin cells. ${ }^{1}$

Erythema multiforme is an acute and selflimiting mucocutaneous hypersensitivity reaction triggered by certain infections and medications. One of the most common predisposing factors for erythema multiforme is infection with herpes simplex virus (HSV). HAEM is an acute exudative dermatic and mucosal disease caused by the infecting HSV. It has a recurrence and idiorestriction, characterised by increasing of $\mathrm{CD} 4+\mathrm{T}$ leucomonocytes. ${ }^{2} 3$

The most common trigger for the development of EM is the HSV (HSV-1 and HSV-2). The

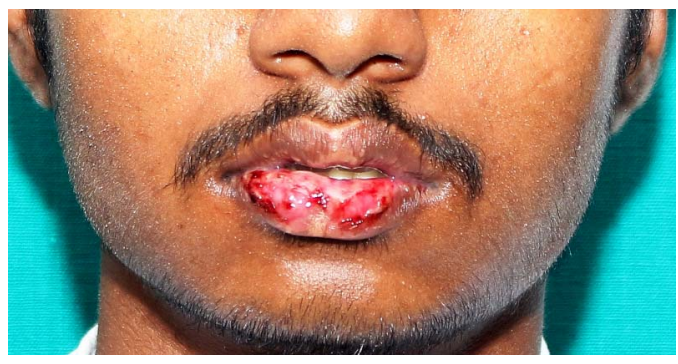

Figure 1 Multiple irregular ulcers with bloody crustations on the lower lip.

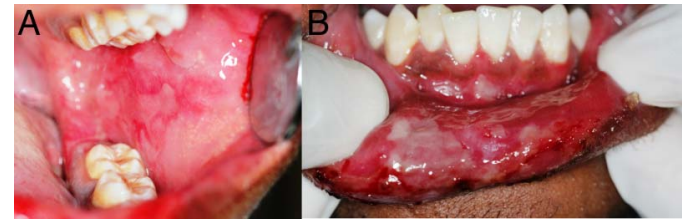

Figure 2 Multiple erosions seen on the left buccal mucosa (A). Gingiva and lower labial mucosa (B). The eroded areas were covered with an erythematous halo.

pathogenesis of HAEM is consistent with a delayed hypersensitivity reaction. The disease begins with the transport of HSV DNA fragments by circulating peripheral blood mononuclear CD34+ cells (Langerhans cell precursors) to keratinocytes, which leads to the recruitment of HSV-specific CD4+ Th1 cells. The inflammatory cascade is initiated by interferon $\gamma(\mathrm{IFN}-\gamma)$, which is released from the CD4 + cells in response to viral antigens, and immunomediated epidermal damage subsequently begins. ${ }^{4}$

An 18-year-old man reported to the department of oral medicine and radiology, with extensive painful ulcers and haemorrhagic crusts on the lower lip for the past 5 days. The patient presented with a 1-week history of fever and headache, for which he took capsules containing dry extract of A. galanga, prescribed by a Siddha physician.Three days later, he developed multiple small ulcerations with fragile haemorrhagic crustations on the lower lip.

Extra-oral examination revealed multiple irregular ulcers with bloody crustations on the lower lip (figure 1). Both submandibular lymph nodes were enlarged and tender. Intraorally, multiple erosions were seen on the left buccal mucosa and gingiva, and these areas were covered with erythematous halos (figure 2). There were no ulcers elsewhere on the body. Based on the drug history and clinical

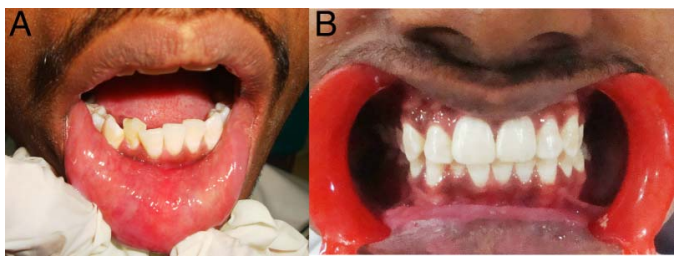

Figure 3 Photographs of the patient, 1 week after treatment, showing complete healing of the oral lesions as seen on the lower labial mucosa (A), and upper and lower gingival region (B). 


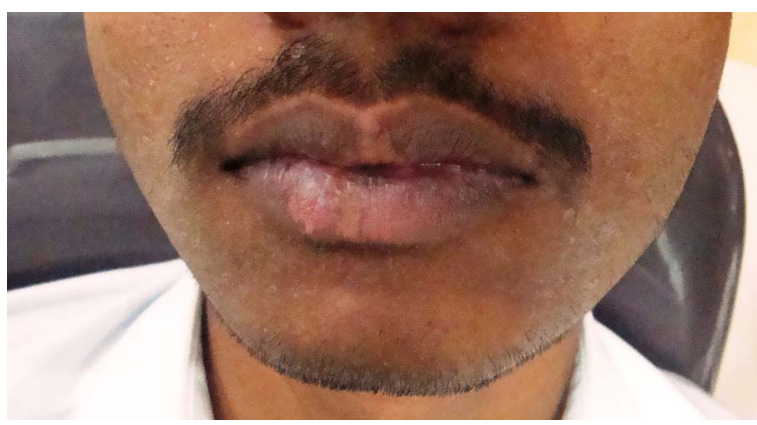

Figure 4 Healing lesions in vermilion border of the lower lip.

findings, a provisional diagnosis of erythema multiforme was made.

Laboratory investigation was carried out for HSV-1 IgG and HSV-2 IgM antibody using the chemoluminescent assay (CLIA) method, and was found to be positive both for HSV-1 IgG and HSV-2 IgM antibody. From the laboratory investigation, we finally concluded the diagnosis to be HAEM. The patient was advised to discontinue the $A$. galanga capsules as they were potentially aggravating his painful oral ulcers.

Treatment of erythema multiforme depends on the severity of the clinical features. Mild forms usually heal in 2-6 weeks; local wound care, topical analgesics or anaesthetics for pain control, and a liquid diet, are often indicated in these situations. For more severe cases, intensive management with intravenous fluid therapy may be necessary. Oral antihistamines and topical steroids may also be necessary to provide symptom relief. Systemic corticosteroids have been used successfully in some patients, but evidence to support their use for erythema multiforme is limited. ${ }^{6}$

The patient was treated with a 1-week course of tablet acyclovir $400 \mathrm{mg} /$ day (5 times a day). He was also advised to apply triamcinolone acetonide $0.1 \%$ oral paste on his lower lip twice daily, and tablet prednisolone $20 \mathrm{mg}$ two times a day was prescribed for 7 days. The patient was reviewed after a week. On follow-up, he presented with healed oral lesions in the lower labial mucosa and gingival region (figure $3 \mathrm{~A}, \mathrm{~B}$ ), and also in the vermilion border of the lower lip ( figure 4). The prednisolone dosage was tapered and stopped over the next 3 days. The patient was advised to continue tablet acyclovir $400 \mathrm{mg} /$ day (two times a day) for 4 months.

\section{Learning points}

- Erythema multiforme is an acute, self-limited mucocutaneous inflammatory disorder associated with viral infections such as herpes simplex virus, Epstein-Barr virus and cytomegalovirus. Drugs, including dioclofenac sodium, sulfonamides and penicillins, also predispose to the development of erythema multiforme.

- Alpinia galanga is a known Siddha drug used by that traditional medicinal system for treating numerous acute and chronic inflammatory disorder. The anti-inflammatory action of $A$. galanga is due to active phytochemical components such as $1^{\prime}$-acetoxychavicol acetate (ACA) and trans-p-hydroxycinnamaldehyde present in it.

- There is little literature describing Siddha drugs such as A. galanga causing erythema multiforme. The erythema multiforme-like reaction is triggered by haptens present in $A$. galanga. In this case, herpes-associated erythema multiforme was exacerbated by $A$. galanga.

Contributors SKM, HKM and VSK contributed to diagnosis of the patient, concept of the paper, acquisition of data and drafting, revision and final approval of the article. SHK contributed to diagnosis of the patient, concept of the paper and drafting, revision and final approval of the article.

Competing interests None declared.

\section{Patient consent Obtained.}

Provenance and peer review Not commissioned; externally peer reviewed.

\section{REFERENCES}

1 Verma Ramesh K, Mishra G, Singh P, et al. Alpinia galanga-an important medicinal plant: a review. Der Pharmacia Sinica 2011;2:142-54

2 Kamala KA, Ashok L, Annigeri RG. Herpes associated erythema multiforme. Contemp Clin Dent 2011;2:372-5.

3 Sokumbi 0 , Wetter DA. Erythema multiforme associated with recurrent herpes infection.Clinical features, diagnosis, and treatment of erythema multiforme: a review for the practicing dermatologist. Int J Dermatol 2012;51:889-02.

4 Shah SN, Chauhan GR, Manjunatha BS, et al. Drug induced erythema multiforme: two case series with review of literature. J Dermatol 2015;42:336-7.

5 Samim F, Auluck A, Zed C, et al. Erythema multiforme: a review of epidemiology, pathogenesis, clinical features, and treatment. Dent Clin North Am 2013;57:583-96.

6 Osterne RL, Matos Brito RG, Pacheco IA. et al. Management of erythema multiforme associated with recurrent herpes infection: a case report. J Can Dent Assoc 2009;75:597-601.

Copyright 2015 BMJ Publishing Group. All rights reserved. For permission to reuse any of this content visit http://group.bmi.com/group/rights-licensing/permissions.

BMJ Case Report Fellows may re-use this article for personal use and teaching without any further permission.

Become a Fellow of BMJ Case Reports today and you can:

- Submit as many cases as you like

- Enjoy fast sympathetic peer review and rapid publication of accepted articles

- Access all the published articles

- Re-use any of the published material for personal use and teaching without further permission

For information on Institutional Fellowships contact consortiasales@bmjgroup.com

Visit casereports.bmj.com for more articles like this and to become a Fellow 